\title{
PENERAPAN REGRESI COX PROPORTIONAL HAZARD UNTUK MENDUGA FAKTOR-FAKTOR YANG MEMENGARUHI LAMA MENCARI KERJA
}

\author{
I Gede Ari Sudana ${ }^{1}$, Ni Luh Putu Suciptawati ${ }^{2}$, \\ Luh PUtu IDa HaRini ${ }^{3}$
}

\author{
1, 2, 3 Jurusan Matematika FMIPA Universitas Udayana, Bukit Jimbaran-Bali, \\ e-mail: ${ }^{1}$ bracoex@gmail.com,, ${ }^{2}$ putusuciptawati@yahoo.co.id, ${ }^{3}$ ballidah@gmail.com
}

\begin{abstract}
Survival analysis is a statistical method that accommodates the collection of censored data. One of popular method in survival analysis is the Cox Proportional Hazard Regression. The Cox Proportional Hazard Regression can be used to see old looking for work where data may contain censored data. This article aims investigate the characteristics of job seekers and the variables that affect old looking for work. To establish the best model using Stepwise Selection method. Prior to that the assumption of Cox Proportional Hazards Regression is tested using log minus log curve. The results obtained from Cox Proportional Hazards Regression model is as follows

$$
H(t, Z) h_{0}(t) e^{\left(-0,27261 \times 1-0,26668 \times 2+1,46875 \times 3_{\text {cerai }}+0,27288 \times 3_{\text {kawin }}\right)} \text {. }
$$
\end{abstract}

Keywords: Survival analysis, Cox proportional hazard regression, old looking for work, unemployment

\section{Pendahuluan}

Analisis sintasan adalah nama modern yang diberikan untuk kumpulan metode statistika yang mengakomodasi data tersensor waktu kejadian (Tableman [5]). Salah satu pemodelan yang umum dan populer digunakan pada analisis sintasan adalah Regresi Cox Proportional Hazard. Regresi Cox Proportional Hazard dapat diterapkan pada bidang ketenagakerjaan. Pada bidang ketenagakerjaan, pengangguran merupakan masalah serius. Salah satu indikator pengangguran adalah lama mencari kerja. Karena dalam data lama mencari kerja terdapat data yang tersensor. Diperlukan analisis khusus untuk menangani kasus lama mencari kerja yaitu menggunakan analisis sintasan dengan metode Regresi Cox Proportional Hazard.

Analisis sintasan, biasanya mengacu pada peubah waktu yang merupakan waktu sintasan, karena peubah waktu akan memberikan waktu pada saat seseorang "bertahan" atas beberapa kasus. Pada analisis sintasan secara khusus mengacu pada kejadian sebagai kegagalan, karena kejadian biasanya berhubungan dengan kematian, terjadinya penyakit, atau suatu pengalaman negatif individu. Namun waktu sintasan bisa saja "waktu kembali bekerja setelah melakukan

${ }^{1}$ Mahasiswa Jurusan Matematika FMIPA Universitas Udayana

${ }^{2,3}$ Staf Pengajar Jurusan Matematika FMIPA Universitas Udayana 
operasi bedah elektif', yang mana dalam beberapa kasus kegagalan adalah kejadian yang positif (Perrigot [4]).Sebagian besar analisis sintasan harus mempertimbangkan kunci analisis masalah yaitu data tersensor. Ada tiga alasan utama, penyebab data tersensor muncul yaitu individu tidak mengalami kejadian, individu hilang dari penelitian, individu mengundurkan diri dari penelitian karena kematian ataupun oleh alasan yang lain (Clark [1]).

Tujuan dari penelitian ini adalah mengetahui gambaran umum/karakteristik pencari kerja, mengidentifikasi peubah yang memengaruhi secara signifikan terhadaplamanya seseorang mencari kerja. Pada penelitian ini, konsep pengangguran yang digunakan adalah konsep pengangguran terbuka (open unemployment). Persamaan model untuk Cox proportional hazard adalah sebagai berikut:

$$
h(t, X)=h_{0}(t) \exp \left(\sum_{i=1}^{p} \beta_{i} x_{i}\right)
$$

Dengan $h_{0}(t)$ adalah baseline hazard yang tidak perlu diketahui, $x_{i}$ adalah peubah-peubah bebas terdiri dari $x_{1}, x_{2}, x_{3} \ldots, x_{p}$, dan $\beta_{i}$ adalah parameter dari peubah-peubah bebas terdiri dari $\beta_{1}, \beta_{2}, \beta_{3}, \ldots, \beta_{p}$. Nilai-nilai dugaan $\beta$ diperoleh dengan memaksimumkan fungsi parsial likelihood (Collet [2]).

\section{Metode Penelitian}

Data yang digunakan pada penelitian ini adalah data sekunder, yaitu berupa data mentah yang didapat dari Sakernas 2012. Peubah yang dicatat adalah peubah daerah tempat tinggal, hubungan dengan kepala rumah tangga, jenis kelamin, status kawin, tingkat pendidikan, pengalaman kerja, dan umur. Untuk langkah analisisnya adalah sebagai berikut:

a. Uji asumsi Regresi Cox Proportional hazard. Pengujian asumsi menggunakan plot $\log$ minus $\log$ atau $\log _{e}\left[-\log _{e} S(t)\right]$ terhadap waktu sintasan $(\mathrm{t})$ untuk setiap peubah bebas. Secara eksplisit asumsi yang harus dipenuhi adalah waktu kejadian saling bebas dan mempunyai distribusi yang identik, semua pengaruh peubah kovariat dimasukan ke dalam model, rasio dari dua angka hazard manapun adalah konstan terhadap waktu kejadian.

b. Model terbaik Regresi Cox Proportional Hazard akan dibentuk menggunakan metode stepwise selection.

\section{Hasil dan Pembahasan}

Pada Gambar 1 dapat dijelaskan bahwa masing-masing kurva dari ketujuh peubah bebas yang diduga memengaruhi lama masa mencari kerja di Provinsi Bali yang terdiri daerah tempat tinggal, hubungan dengan kepala rumah tangga, jenis kelamin, status kawin, tingkat pendidikan, pengalaman kerja, dan umur membentuk garis sejajar atau pararel. Hal ini berarti ketujuh peubah bebas 
tersebut dapat memenuhi asumsi regresi cox proportional hazard dan dapat digunakan dalam model.

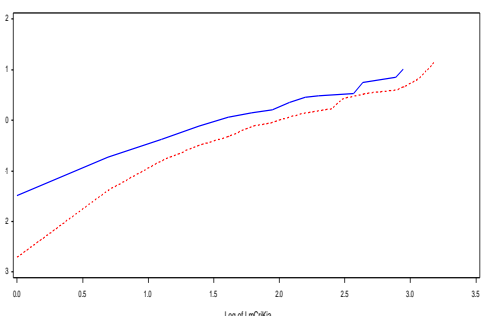

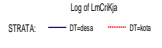
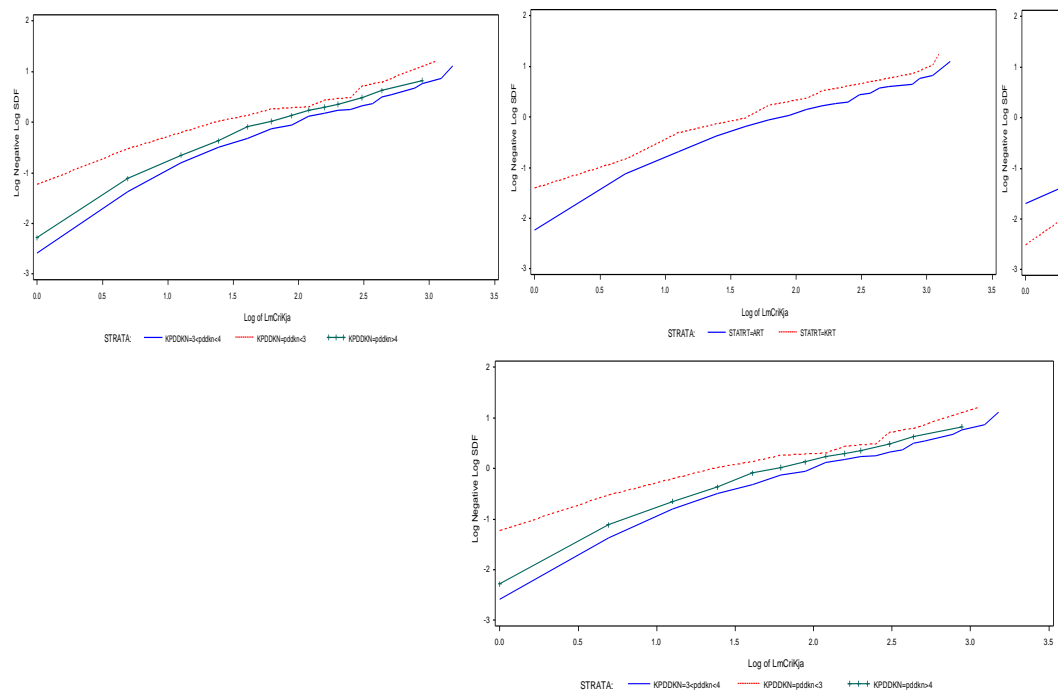

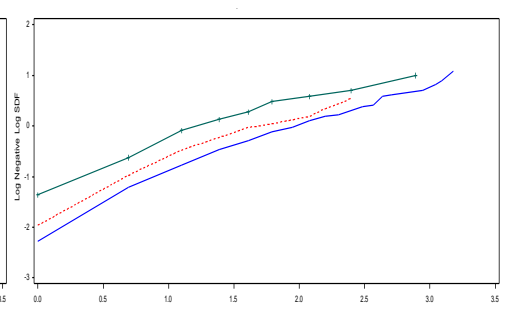

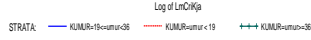
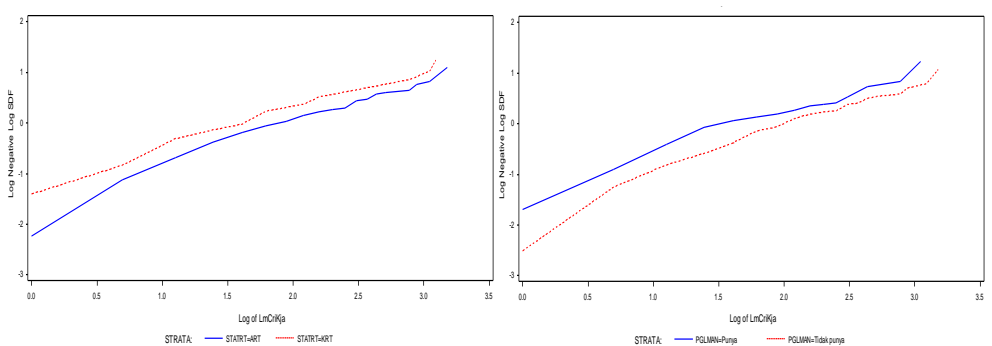

Gambar 1. Kurva LML Waktu Sintasan Lama Mencari Kerja Untuk ketujuh peubah bebas

Untuk mendapatkan model terbaik dari Regresi Cox Proportional Hazard digunakan metode stepwise selection dengan nilai taraf masuknya sebesar 0,05 dan taraf keluarnya 0,1. Dengan bantuan SAS 9.2 maka didapatkan hasil dari stepwise selection sebagai berikut:

Tabel 1. Hasil Akhir Dari Stepwise Selection di Regresi Cox Proportional Hazard.

\begin{tabular}{|l|l|c|c|c|c|r|}
\hline Peubah & DF & $\begin{array}{l}\text { Estimasi } \\
\text { Parameter }\end{array}$ & $\begin{array}{l}\text { Standar } \\
\text { Error }\end{array}$ & $\begin{array}{l}\text { Chi- } \\
\text { Square }\end{array}$ & Pr>ChiSq & $\begin{array}{l}\text { Rasio } \\
\text { Hazard }\end{array}$ \\
\hline $\begin{array}{l}\text { Daerah Tempat } \\
\text { Tinggal (Kota) }\end{array}$ & 1 & $-0,27261$ & 0,13267 & 4,2090 & 0,0402 & 0,761 \\
\hline $\begin{array}{l}\text { Jenis Kelamin } \\
\text { (Perempuan) }\end{array}$ & 1 & $-0,26668$ & 0,13556 & 3,8701 & 0,0492 & 0,766 \\
\hline Status Kawin & 2 & & & 47,29991 & 0,0001 & \\
\hline (Cerai) & 1 & 1,46875 & 0,25803 & 32,4004 & 0,0001 & 4,344 \\
\hline (Kawin) & 1 & 0,27288 & 0,13736 & 3,9463 & 0,0470 & 1,314 \\
\hline
\end{tabular}

Berdasarkan tabel 1. maka dapat disimpulkan bahwa model terbaik dari Regresi Cox Proportional Hazard adalah: 


$$
H(t, Z)=h_{0}(t) e^{\left(-0,27261 \times 1-0,26668 \times 2+1,46875 \times 3_{\text {cerai }}+0,27288 \times 3_{\text {kawin }}\right)}
$$

Dengan $h_{0}(t)$ merupakan baseline hazard yang tidak perlu ditentukan, $X_{1}$ didefinisikan sebagai peubah daerah tempat tinggal dengan desa sebagai referensinya, $X_{2}$ didefinisikan sebagai peubah Jenis Kelamin dengan laki-laki sebagai referensinya, $X_{3}$ merupakan peubah Status Kawin dengan belum kawin sebagai referensinya sehingga muncul dua buah parameter yaitu $\mathrm{X} 3_{\text {cerai }}$ dan $\mathrm{X} 3_{\text {kawin }}$.

\section{Kesimpulan}

Dengan menggunakan Stepwise Selection diperoleh pemodelan regresi Cox sebagai berikut: $H(t, Z) h_{0}(t) e^{\left(-0,27261 \times 1-0,26668 \times 2+1,46875 \times 3_{\text {cerai }}+0,27288 \times 3_{\text {kawin }}\right)}$. Dengan peubah desa sebagai referensinya maka hal ini mengindikasikan bahwa individu yang tinggal kota memiliki kesempatan mendapatkan pekerjaan lebih kecil 0,761 kali dibanding individu yang tinggal di desa. Dengan peubah laki-laki sebagai referensinya maka hal ini mengidikasikan bahwa individu yang berjenis kelamin perempuan memiliki kesempatan mendapatkan pekerjaan lebih kecil 0,766 kali dibanding dengan individu yang berjenis kelamin laki-laki. Sedangkan untuk peubah status kawin yang berpengaruh secara signifikan dengan peubah belum kawin sebagai referensinya didapatkan koefisien regresi positif dengan nilai $e^{1,46875}$ adalah 4,344 untuk peubah status kawin yang cerai dan nilai $e^{0,27288}$ adalah 1,314 untuk peubah status kawin yang sudah kawin. Hal ini mengindikasikan bahwa individu yang cerai memiliki kesempatan mendapatkan kerja lebih besar 4,344 kali dari individu yang belum kawin sedangkan untuk individu yang sudah kawin kesempatan mendapatkan pekerjaan lebih besar 1,314 kali dari individu yang belum kawin.

\section{Daftar Pustaka}

[1] Clark, TG., Bradburn, MJ., Love, SB., Altman, DG. 2003. "Survival Analysis Part I: Basic concepts and first analyses". British Journal of Cancer, 89, 232-238.

[2] Collet,D. 2003. Modeling Survival Data In Medical Research Second Editon. London : Chapman and Hall.

[3] Kleinbaum, D. G. dan Klein, M. 2005. Survival Analysis: Statistics for Biology and Health. Second edition. Spinger-Verlag. New York.

[4] Perrigot, Rozenn., Cliquet, Gerard., Mesbah, Mounir. 2004. "Possible Applications of Survival Analysis in Franchising Research". Int. Rev. Of Retail, Distribution and Consumer Research, Vol. 14, No. 1, 129-143.

[5] Tableman, Mara. 2008. Survival Analysis Using $S / R^{*}$. Portland State University. Portland. 